\author{
Удовиця О.Ф. \\ кандидат педагогічних наук, доцент \\ кафедра менеджменту і логістики \\ E-mail: oleg.may67@yandex.ru \\ Пасчина Г.П. \\ студентка 4 курсу фракультету менеджменту, маркетингу і логістики \\ Одеська національна академія харчових технологій \\ вул. Канатна, 112, м. Одеса, Україна, 65039 \\ E-mail: paschynah@mail.ru
}

\title{
УДОСКОНАЛЕННЯ СИСТЕМИ МОТИВАЦІЇ ПЕРСОНАЛУ НА ВІТЧИЗНЯНИХ ПІДПРИЄМСТВАХ ВИНОРОБНОЇ ГАЛУЗІ (НА ПРИКЛАДІ ПрАТ «ОДЕСАВИНПРОМ»)
}

\begin{abstract}
У статті проведено системний аналіз існуючих технологій мотивування персоналу виноробних підприємств, на прикладі ПрАТ «Одесавинпром», запропоновано методику удосконалення системи управління персоналом підприємств виноробної галузі із використанням чинників мотивації.

Ключові слова: персонал, управління персоналом, методи та засоби мотивації персоналу, виноробне підприємство, організаційна структура.
\end{abstract}

This work is licensed under a Creative Commons Attribution 4.0 International License http://creativecommons.org/licenses/by/4.0/

Постановка проблеми та її зв'язок $з$ важливими науковими та практичними завданнями. Зміни в економіці України ускладнюються багатьма проблемами, серед яких особливе місце займає протиріччя між необхідністю активізації ролі людського фактору й незадовільним станом його мотивації щодо підвищення ефективності праці. Дана проблема $є$ багатогранною й складною для рішення на різних рівнях, оскільки тісно пов'язана із готовністю виноробних підприємств до викликів сьогодення й необхідністю підвищення їх конкурентоспроможності на світовому (європейському) ринках.

Людина - не машина, і в неї є бажання та намічені певні цілі. Будь-які конкретні види діяльності, у тому числі праця, здійснюються у зв'язку 3 внутрішніми потребами особистості. 3 одного боку, практично апробовано механізм примусової мотивації, який забезпечує підлеглому матеріальну або іншу компенсацію відповідного рівня, з іншого боку, вважаються більш ефективними інші моделі мотивації, які засновані на принципах особистої зацікавленості самих працівників, коли ті або інші дії здійснюються ними усвідомлено через внутрішні спонукальні мотиви.

Основу сучасної концепції управління персоналом організації складають зростаюча роль особи працівника, знання його мотиваційних установок, уміння їх формувати і направляти відповідно до завдань, що стоять перед організацією [3, с. 55].

Аналіз останніх публікацій по проблемі. С.Г.Турчіна вважає, що сьогодні ефективна система мотивації персоналу формується переважно на застосуванні економічних методів управління. Це значить що керівники всіх рівнів управління повинні знати та вміти практично застосовувати економічні важелі впливу на колективи та окремих працівників [11, с. $313]$.

Окремі виноробні підприємства створюють своїм членам (методами регулювання й економічного перерозподілу) базу матеріального добробуту, яка мотивує людину до можливо більш повної реалізації свого потенціалу. На думку Т.А.Костишиної система управління мотивацією працівника повинна базуватися на науково обгрунтованих методиках визначення характеру соціально-психологічних методів впливу на поведінку працівника. Лише в результаті створення умов для реалізації особистих інтересів у поєднанні з колективними та суспільними можливо досягнення конкретно вираженої зацікавленості працівників у ефективній діяльності підприємства [7,с.18-21].

О.Ю. Шалевська одним 3 основних напрямків, який спонукає робітника працювати краще, вважає соціальні чинники у вигляді будівництва житла для працівника, погашення заборгованості за комунальні послуги, кредиту за автомобіль, пільгове постачання працівників продукцією підприємства та ін. [12, с. 85].

C.I. Панченко, у свою чергу, вважає, що одним із головних факторів досягнення високих показників продуктивності праці $\epsilon$ фінансова мотивація працівників підприємства. Особливого значення такий чинник мотивації праці набуває в умовах функціонування підприємств, які характеризуються низьким рівнем технічного забезпечення виробничих процесів, нестачею 
необхідних обігових коштів та низькою зацікавленістю працівників у результатах своєї праці [8, c. 95].

Теорія і практика мотивації праці в Україні зводиться, в основному, до оплати праці, що заснована на фіксованих тарифних ставках i посадових окладах, які в недостатній мірі спонукають людину до трудової активності через задоволення потреб працівника. [6, с. 134].

Т.О. Жолтікова вважає, що основний зміст роботи в області матеріальної винагороди робітників підприємств - визначити об'єм праці, та розмір іiі оплати. Розробка оптимальних співвідношень в оплаті праці різної складності є найбільш важливим моментом у системі диференціації заробітної плати. Такий підхід має забезпечувати відповідність розмірів оплати праці його якісним показникам та результативності [5, с. 147].

Формулювання цілей дослідження. У статті наведено аналіз існуючих систем мотивації персоналу виноробних підприємств, на прикладі ПрАТ «Одесавинпром». Мета роботи - виявлення слабких місць управління виробничим персоналом та запропонування методиці удосконалення системи управління персоналом підприємств виноробної галузі із використанням чинників мотивації.

Виклад основних результатів та їх обгрунтування. Основою оптимального «життєвого циклу» робочої сили є встановлення гарантованого мінімуму оплати праці (доходу) на базі мінімального споживчого бюджету, що забезпечує соціальну захищеність усіх категорій працюючих на виробництві. Виходячи з вимог збереження відтворної функції оплати праці й посилення соціальної захищеності працівників підприємств їі мінімальна величина може визначатися за науково розробленою методикою на основі розрахунку прожиткового мінімуму, що включає в себе набір мінімально необхідних життєвих засобів і послуг (споживчий кошик). Відповідно до вимог трудового законодавства розмір матеріального заохочення визначається з урахуванням результатів праці працівника, тривалості його безперервного стажу роботи в організації. Положення про виплату винагороди затверджується адміністрацією й узгоджується 3 профспілкою. Винагорода виплачується після підведення підсумків господарської діяльності.

У сфері доходів і споживання важливого значення набуває формування фонду життєзабезпечення (у грошовій і натуральній формах) робітників на рівні, який забезпечує постійне оновлення робочої сили за інтенсивним типом, захист прав споживачів, підвищення культури споживання, розвиток особистих потреб. Розподільна політика повинна передбачати посилення залежності між результатами праці й доходом.

Мотивація в цьому випадку забезпечує відтворювальну функцію, тобто заробітна плата повинна компенсувати витрати праці, причому в розмірах не менш рівня прожиткового мінімуму. Стимулювання повинне виявитися в забезпеченні взаємозв'язку розмірів оплати праці й конкретних результатів трудової діяльності працівника виноробного підприємства. Питання, які стосуються рівня заробітної плати, можна віднести до системи управління персоналом. Необхідно встановити достатні оклади для працівників відповідно до рівня їхньої освіти, кваліфікації, стажу роботи, займаною посадою, що має на увазі певну відповідальність, обсяги і якість виконуваних робіт. Все зазначене буде сприяти створенню умов комфорту, залученню й утриманню кваліфікованих кадрів, а також їх ефективному використанню.

Для підвищення ефективності управління персоналом виноробного підприємства необхідно, насамперед, зміцнити найбільш слабку ланку систему мотивації трудової діяльності працівника. Управління працею персоналу пропонується будувати 3 урахуванням природи мотивації. Для формування раціональної поведінки працівника, яка проявляється у прийнятті оптимальних для цілей підприємства рішень і здійсненні відповідних дій, використовуються заходи впливу на його особисті інтереси шляхом побудови та застосування системи управління працею, що враховує особливості праці в заданих умовах діяльності. Сутність мотивації праці полягає у впливі стимулів праці на інтереси працівника. Головний особистий інтерес працівника прагнення отримати дохід від роботи. Тому оплата праці лежить в основі всіх систем мотивацій працівника до праці.

Структура заробітної плати на ПрАТ «Одесавинпром» включає в себе, крім основної заробітної плати, всілякі надбавки: за трудовий стаж, кваліфікацію, понаднормативну діяльність, тощо. Основна заробітна плата являє собою місячний посадовий оклад за штатним розкладом, узгоджений 3 працівником при наймі на роботу в контракті.

3 метою дослідження задоволеністю умовами праці було проведено анкетування співробітників. Були задані питання за трьома основними показниками:

- психологічним кліматом на підприємстві;

- задоволеність оплатою праці;

- задоволеність загальна задоволеність від результатів діяльності.

Аналіз показав, що на досліджуваному підприємстві недостатньо компонентів альтернативного заохочення. В той же час серед співробітників існує стійка потреба в додаткових факторах системи матеріального стимулювання. Найбільш бажані компоненти матеріального заохочення, які хотіли б бачити співробітники компанії, - це: «базовий оклад»; надбавки за додаткові функції (по суті, прихована форма збільшення окладу); премія; одноразова допомога у зв'язку з відходом на пенсію; працівникам, що досягли ювілейного віку 50, 55, 60 років, нагородженим грамотою, згідно з наказом; пенсіонерам, на лікування щорічно. Крім того, робітники очікують від керівництва наступні виплати: оплата ритуальних послуг; жінкам при народженні дитини; у разі смерті в результаті нещасного випадку на виробництві; малозабезпеченим та багатодітним сім'ям. 
Тобто сутність мотивації праці полягає у впливі стимулів праці на інтереси працівника. Головний особистий інтерес працівника - прагнення отримати дохід від роботи.

Типові форми і системи заробітної плати коригуються з урахуванням умов роботи підприємства та вибраних цілей його розвитку. Використовуються різні варіанти і комбінації елементів організації заробітної плати: ставок, окладів, відрядного приробітку, доплат і надбавок, різних видів і розмірів преміювання. Їх поєднання у скоригованій системі заробітної плати по-різному впливатиме на розмір, склад і динаміку оплати праці.

До неекономічних способів мотивації відносяться організаційні та морально-психологічні (залучення працівників до участі в справах організації, надання нових знань та навичок, збагачення змісту роботи). Морально-психологічні методи стимулювання мають на меті створення умов, при яких люди відчували б професійну гордість за те, що краще за інших можуть впоратися 3 дорученою роботою, причетність до неї, відповідальність за їі результати; відчували б цінність результатів, конкретну їх важливість. Для того щоб робота приносила задоволення, завдання повинне містити певну частку ризику і можливість домогтися успіху.

Керівники різних рівнів повинні завжди пам'ятати й враховувати те, що сучасне суспільство об'єктивно формує в людей не тільки високі стандарти матеріального споживання, але й задає загальні соціальні установки щодо життєвого стандарту: якості житла, індивідуальних засобів переміщення. Це не просто загальні соціокультурні положення про економічну норму життя, а діючий стимул і фактор оцінки економічного поводження.
Для кожного конкретного працівника характерний індивідуальний набір, персональний комплекс мотивуючих факторів.

Важливим засобом підвищення матеріальної зацікавленості працівників в поліпшенні кінцевих результатів підприємств є преміювання. Будь-яка преміальна система включає такі параметри: показники преміювання, умови преміювання, розміри і шкалу преміювання, круг працівників, періодичність преміювання. При організації преміювання особливо важливим $\epsilon$ питання вибору і обгрунтування показників преміювання, які розділяються на основні і додаткові. Основними вважаються показники, досягнення яких має вирішальне значення для вирішення проблем, що стоять перед колективом або цими працівниками. Додаткові показники преміювання повинні стимулювати різні менш значимі аспекти трудової діяльності. Всі показники преміювання мають бути конкретними, чітко сформульованими, легко враховуватися. Окрім цього, їх не повинно бути більше, ніж 2-3 (максимум 4), інакше увага працівника може розсіюватися за декількома показниками. Тому у кожному конкретному випадку потрібно обирати найбільш важливі виробничі показники. Крім виконання основних та додаткових критеріїв, розмір та шкала преміювання та періодичність виплати також мають суттєвий вплив на результативність такого виду стимулювання.

Як свідчить статистика, у кожного працівника мотиваційна основа є індивідуальною і обумовлюється рядом чинників: рівнем добробуту, соціальним статусом, кваліфікацією, посадою, ціннісними орієнтаціями і тому подібне. Мотиваційний механізм різних категорій працівників управління приведений на рис. 1.
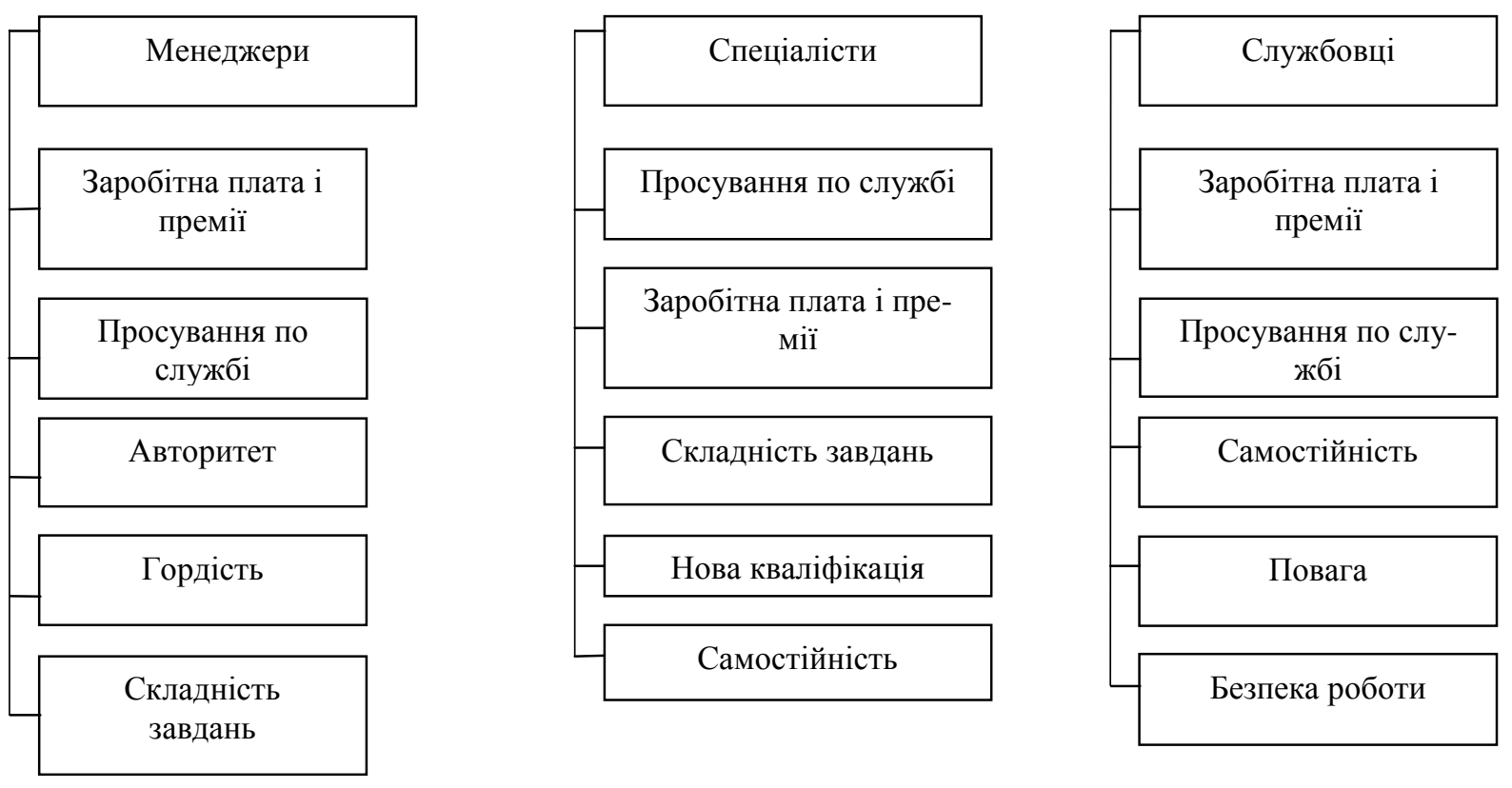

Рис. 1. Ієрархічна схема мотиваційного механізму персоналу підприємства*

*авторська розробка 
Дослідження вітчизняних і зарубіжних учених свідчать, що за умов повного матеріального достатку лише $20 \%$ людей не бажають працювати ні за яких обставин, $36 \%$ - готові працювати у разі виконання цікавої і змістовної роботи, $21 \%$, щоб уникнути самотності і нудьги, $14 \%$, щоб не втратити себе як особу, 9\% - тому, що робота приносить радість [13, c.64.]

Однією 3 найважливіших потреб кожної людини є потреба у вільному часі та сприятливому режимі роботи. До пріоритетних напрямів посилення мотивації трудової діяльності персоналу, відносять регулювання робочого часу й заохочення їх вільним часом. Основними підходами до регулювання робочого часу і заохочення вільним часом $є$ :

- надання додаткового вільного часу. Цей засіб мотивації праці реалізується шляхом зміни тривалості основної та додаткових відпусток, їх ділення на певні частини (наприклад, надання іх влітку та зимою), надання можливості працювати неповний робочий день або неповний робочий тиждень, тощо.

- перерозподіл робочого часу. Цей метод стимулювання реалізується через надання працівнику можливості особисто визначати початок, закінчення та тривалість робочого дня ( за умови дотримання місячної норми робочого часу), обов'язкового виконання встановлених трудових норм, збереженні встановленого виробничого процесу.

Сучасною формою стимулювання є участь у підприємництві, що включає участь в управлінні, в прибутку, у власності. У цьому випадку дохід ділиться на дві частини і заробітна плата встановлюється мінімальною. Участь у прибутку,перш за все пов'язана 3 розподілом іiі додаткової величини, до $75 \%$ якої може діставатися персоналу. Здійснюються такі виплати зазвичай щомісяця, щоб люди могли наочно бачити конкретні результати своїх зусиль. Прибутки можуть виплачуватися як у складі загальної заробітної плати, так і у вигляді доповнення до мінімальної. Система участі в прибутках обмежена тим, що не всі фактори росту прибутку залежать від працівника.

Морально-психологічні методи стимулювання мають на меті створення умов, при яких люди відчували б професійну гордість за те, що краще за інших можуть впоратися 3 дорученою роботою, причетність до неї, відповідальність за її результати; відчували б цінність результатів, конкретну їх важливість. Для того щоб робота приносила задоволення, завдання повинне містити певну частку ризику і можливість домогтися успіху.

Участь в успіху - це форма оплати праці, при якій розмір винагороди за кожний період часу більш за все залежить від певних відмінних якостей працівника і від розміру прибутку, отриманого підприємством за відповідний період часу.

Вважається, що питання винагороди - внутрішня справа кожного роботодавця. Як правило, підприємство самостійно розробляє систему управління працею, що як важливішу складову включає систему винагороди (як правило, такі питання становлять комерційну таємницю).
Пропонується наступний перелік заохочень, які мають підвищити ефективність управління персоналом i, як слідство - продуктивність праці, збільшити кількість та якість продуктів виробництва i, як слідство конкурентоспроможність підприємства:

- кращим працівникам, кожний рік (після атестування) збільшується зарплатня; 5-10 років;

- премія за вислугу років виплачується через

- працівнику надається оплачуване запрошення на два обіди (вечері) у першокласному ресторані на суму еквівалент - 100 доларів, якщо він за весь рік жодного разу не брав відпустки через хворобу;

- відділ управління персоналом підприємства приймає безпосередню участь у вирішенні особистих проблем робітника;

- видається оплачений чек на повне медичне обстеження в кращих медичних закладах регіону;

- здійснюється страхування життя і здоров'я працівника за рахунок підприємства;

- на підприємстві відкривається субсидований для персоналу магазин, їдальня, кафетерій;

- надаються позики 3 пільговою процентною ставкою на навчання дітей працівників у вишах;

- організуються дитячі установи;

- організуються колективні гаражі;

- практикується підвищення на посаді без зміни заробітної плати;

- надається окремий кабінет для роботи;

- надається право на безкоштовне користування службовим автомобілем;

- компенсуються витрати на бензин та ремонт власного автомобіля працівника;

- керівникам вищої ланки, які працюють 1015 років, зробили особистий внесок у розвиток організації надається оплачена відпустка терміном від 6ти місяців до одного року.

Тому вважаємо, що управління мотивацією праці персоналу включає послідовне виконання поетапних заходів:

а) вибір мотиваторів праці;

б) політику заробітної плати;

в) політику винагороди та послуг;

г) політику участі в успіху;

д) управління витратами на персонал.

Таким чином, одним 3 основних напрямків підвищення ефективності використання персоналу підприємства є посилення мотивації праці. В основі мотивації праці лежить використання різноманітних мотивів, серед яких слід виділити матеріальні, моральні, соціально-психологічні, духовні, творчі та ін. Виділено такі основні форми стимулювання працівників підприємства: заробітна плата; соціальні виплати; нематеріальні пільги; дивіденди за акціями підприємства; заходи, що підвищують змістовність праці, створення сприятливої соціальної атмосфери; просування працівників по службі. Дані заходи щодо підвищення мотивації праці дозволяють більш ефективно використовувати трудовий потенціал підприємства та підвищити його конкурентоспроможність на ринку. 
Висновки та перспективи подальших досліджень. На основі приведених даних можна зробити наступні висновки:

- основу матеріального стимулювання працівників будь-якої сфери діяльності складає заробітна плата;

- мотивація співробітників займає одне 3 центральних місць в управлінні персоналом підприємства, оскільки вона виступає безпосередньою причиною їх поведінки;

- оплата праці працівників складається з основної і додаткової заробітної плати. Основна заробітна плата працівника визначається тарифними ставками, розцінками, посадовим окладом. Рівень додаткової оплати праці встановлюється відповідно до кінцевих результатів діяльності підприємства і трудового вкладу співробітника;
- важливим засобом підвищення матеріальної зацікавленості працівників в поліпшенні кінцевих результатів підприємства є преміювання. Для підвищення стимулюючої ролі премії необхідно, в першу чергу, визначитися з метою преміювання.

Важливо правильно оцінювати ситуацію, в рамках якої матеріальне стимулювання реалізується, як головне, намагатися не перебільшувати його можливості, враховуючи, що людина характеризується дуже складною системою потреб, інтересів, пріоритетів і цілей. Будь-які види стимулювання повинні бути цільовими і відкритими, тому що чекати від працівників покращення ефективності та якості виконуваної роботи можна тільки тоді, коли вони знають, що їхня праця оцінюється справедливо.

\title{
Література
}

1. Бесенюк В.М. Ефективність використання людського капіталу в агроформуваннях Івано-Франківської області / В.М.Бесенюк // Економіка: проблеми теорії та практики. - 2005. - С. 562-569.

2. Беспалов В.А. Стратегия и тактика совершенствования управления персоналом / В.А. Беспалов, М.В. Баранова // Наук. пр. ПФ НУБіП України «КАТУ»: економічні науки. - 2008. - Вип 121. - С. 36-39.

3. Десслер Г. Управление персоналом / Десслер Г. - М.: БИНОМ, 1997. - 246 с.

4. Ерохина Л.В. Мотивация труда и проблемы ее использования / Ерохина Л.В. // Зб. наук. пр. Луганського національного аграр. ун. - 2002. - №14 (26). - С. 311-314.

5. Жолтікова Т.О. Стимулювання праці в сільському господарстві України / Жолтікова Т.О. // Наук.пр. НУБіП ПФ «КАТУ»: економічні науки. - 2008. - № 114. - с. 147-150.

6. Ігнатенко М.М. Досвід праці працівників аграрних підприємств в зарубіжних країнах / М.М. Ігнатенко // Наук. пр. НУБіП ПФ «КАТУ»: економічні науки. - 2008. - № 114. - С. 134-139.

7. Костишина Т.А. Мотивація.основи оплати праці на підприємствах торгівлі різних форм власності / Т.А.Костишина // Україна: аспекти праці. - 1998. - №2. - С. 18-21.

8. Панченко C.I. Мотивація праці як фактор підвищення продуктивності праці в сільському господарстві / C.I. Панченко // Вісн. ХНАУ ім. В.В.Докучаєва. Сер. «Економіка АПК і природокористування». - 2009. - №14. - С. $95-101$.

9. Прока Н.И. Управление системой мотивации персонала - основа повышения конкурентоспособности аграрного производства / Н.И. Прока // Наук. вісн. НАУ. - 2007. - №111. - С. 16-21.

10. Самыгин С.И. Менеджмент персонала: [учеб. пособ. для вузов] / С.И. Самыгин. - М.: Феникс: Зевс, 2004. $478 \mathrm{c}$.

11. Турчіна С.Г. Кадрове забезпечення та якісний склад персоналу в сільськогосподарських підприємствах / С.Г. Турчіна // Збірн. наук. пр. Луганського національного аграрного університету. - 2002. - №14( 26). - С. 311-314.

12. Шалевська О.Ю. Чинники впливу на мотивацію праці в сільському господарстві / О.Ю.Шалевська // Економіка АПК. - 2010. - №8. - С. 81-85.

13. Менеджмент персоналу: навч. посіб / [Данюк В.М., Петюх В.М., Цимбалюк С.О. та ін.] ; за заг. ред. В. М. Данюка, В. М. Петюха. - [2-е вид., без змін]. - К.: КНЕУ, 2006. - 398 с.

Стаття надійшла 4.04.2017 Стаття прийнята до друку 18.04.2017 Доступно в мережі Internet 30.06.2017

\author{
Удовица О.Ф.
}

кандидат педагогических наук, доцент кафедра менеджмента и логистики

E-mail: oleg.may67@yandex.ru

Пасчина А.П.

студентка 4 курса фракультета менеджмента, маркетинга и логистики Одесская национальная академия пищевых технологий ул. Канатная, 112, г. Одесса, Украина, 65039

E-mail: paschynah@mail.ru

\section{УСОВЕРШЕНСТВОВАНИЕ СИСТЕМЫ МОТИВАЦИИ ПЕРСОНАЛА НА ОТЕЧЕСТВЕННЫХ ПРЕДПРИЯТИЯХ ВИНОДЕЛЬЧЕСКОЙ ОТРАСЛИ (НА ПРИМЕРЕ ЧАО «ОДЕССАВИНПРОМ»)}

В статье проведен обзор методов и инструментов повышения мотивации производственного персонала, а так же анализ действующей системы стимулирования производственного персонала на украинских предприятиях винодельческой промышленности на примере ЧАО "Одессавинпром" с целью выяв- 
ления слабых мест управления производственным персоналом.

Для повышения эффрективности управления персоналом винодельческого предприятия необходимо прежде всего укрепить наиболее слабое звено - систему мотивации трудовой деятельности работника. Управление трудом персонала предлагается строить с учетом природы мотивации. Сущность мотивации труда заключается в воздействии стимулов труда на интересы работника. Главный личный интерес работника - стремление получить доход от работы. Поэтому оплата труда лежит в основе всех систем мотиваций работника к труду. Важным средством повышения материальной заинтересованности работников в улучшении конечных результатов предприятий является премирование. При организации премирования особенно важным является вопрос выбора и обоснования показателей премирования, которые делятся на основные и дополнительные. Основными считаются показатели, достижение которых имеет существенное значение для решения проблем, стоящих перед коллективом или этими работниками. Подробную внимание уделено понятиям "мотивация", "мотив" и "стимул". В основе мотивации труда лежит использование разнообразных мотивов, среди которых следует выделить материальные, моральные, социальнопсихологические, духовные, творческие и др.

С целью исследования удовлетворенности условиями труда было проведено анкетирование сотрудников. Были заданы вопросы по трем основным показателям: удовлетворенность оплатой труда; удовлетворенность психологическим климатом на предприятии; общая удовлетворенность результатами деятельности.

На основе этих исследований предложены практические рекомендации по совершенствованию систем управления и мотивации работников предприятий винодельческой отрасли с использованием факторов мотивации.

Ключевые слова: персонал, управление персоналом, методы и способы мотивации персонала, винодельческое предприятие, организационная структура.

\author{
Udovitsa 0. \\ Ph.D., Associate Professor \\ Department of Management and Logistics \\ E-mail: oleg.may67@yandex.ru \\ Paschyna $\mathrm{H}$. \\ The student of the fourth grade of Management, Marketing and Logistics Faculty \\ Odessa National Academy of Food Technologies \\ Kanatna str., 112, Odesa, Ukraine, 65039 \\ E-mail: paschynah@mail.ru
}

\title{
IMPROVEMENT OF THE SYSTEM OF PERSONNEL MOTIVATION AT DOMESTIC ENTERPRISES OF VINE MAKING INDUSTRY (IN THE CASE OF PJSC "ODESAVINPROM")
}

The article provides an overview of the theoretical foundations regarding methods and tools for increasing the motivation of production personnel. There you can familiarize with the analysis of the current system of stimulation of production personnel at the Ukrainian enterprises of the wine industry on the example of PJSC "Odesavinprom". The purpose is to reveal weaknesses of management of production personnel.

To increase the efficiency of human resource management of the wine-making company's personnel, first of all it is necessary to strengthen the weakest link - the motivation system for the worker's activity. Personnel management is proposed to be built taking into account the nature of the motivation. The essence of work motivation is the impact of labour incentives on the employee's interests. The main personal interest of the employee is the desire to get income from work. Therefore, wages are at the core of all employee motivation systems for work. Bonuses are an important means of increasing the material incentive of employees to improve the final results of enterprises. When organizing bonuses, it is especially important to choose and justify the bonuses, which are divided into main and additional ones. The main ones are indicators, the achievement of which is crucial for solving the problems facing the team or these employees. The detailed attention is paid to the notion of "motivation", "motive" and "stimulus". The motivation for work is based on the use of various motives, among which there are material, moral, socio-psychological, spiritual, creative, etc. 
For the purpose of researching satisfaction with working conditions, employees were questioned. Questions were asked highlights three main issues: satisfaction with pay; Satisfaction with the psychological climate in the enterprise; Overall satisfaction with performance.

On the basis of these studies, conclusions were drawn on practical recommendations for improving management and motivation systems for workers in the wine industry using motivation factors.

Keywords: personnel, human resource management, methods and ways of motivation of personnel, wine-making enterprise, organizational structure.

\section{References}

1. Beseniuk, V. M. (2005). Efektyvnist vykorystannia liudskoho kapitalu v ahroformuvanniakh IvanoFrankivskoi oblasti. Ekonomika: problemy teorii ta praktyky, 562-569.

2. Bespalov, V. A. (2008). Stratehyia y taktyka sovershenstvovanyia upravlenyia personalom . Nauk. pr. PF NUBiP Ukrainy «KATU»: ekonomichni nauky, 121, 36-39.

3. Dessler, H. (1997). Upravlenye personalom . M.: BYNOM.

4. Erokhyna, L. V. (2002). Motyvatsyia truda y problemы ee yspolzovanyia. Zb. nauk. pr. Luhanskoho natsionalnoho ahrar. un., 14(26), 311-314.

5. Zholtikova , T. O. (2008). Stymuliuvannia pratsi v silskomu hospodarstvi Ukrainy . Nauk.pr. NUBiP PF «KATU»: ekonomichni nauky, 114, 147-150.

6. Ihnatenko, M. M. (2008). Dosvid pratsi pratsivnykiv ahrarnykh pidpryiemstv v zarubizhnykh krainakh. Nauk. pr. NUBiP PF «KATU»: ekonomichni nauky, 114, 134-139.

7. Kostyshyna , T. A. (1998). Motyvatsiia.osnovy oplaty pratsi na pidpryiemstvakh torhivli riznykh form vlasnosti. Ukraina: aspekty pratsi, 2, 18-21.

8. Panchenko , S. I. (2009). Motyvatsiia pratsi yak faktor pidvyshchennia produktyvnosti pratsi v silskomu hospodarstvi . Visn. KhNAU im. V.V.Dokuchaieva. Ser. «Ekonomika APK i pryrodokorystuvannia», 14, 95-101.

9. Proka, N. Y. (2007). Upravlenye systemoi motyvatsyy personala - osnova povыshenyia konkurentosposobnosty ahrarnoho proyzvodstva . Nauk. visn. NAU, 111, 16-21.

10. Sambhyn, S. Y. (2004). Menedzhment personala. M.: Fenyks: Zevs. APK, 8, 81-85.

11. Shalevska , O. I. (2010). Chynnyky vplyvu na motyvatsiiu pratsi v silskomu hospodarstvi . Ekonomika

12. Shalevska , O. I. (2010). Chynnyky vplyvu na motyvatsiiu pratsi v silskomu hospodarstvi . Ekonomika APK, 8, 81-85.

KNEU.

13. Daniuk , V. M., Petiukh, V. M., \& Tsymbaliuk, S. O. (2006). Menedzhment personalu: navch. posib . K.:

Received 4 April 2017

Approved 18 April 2017

Available in Internet 30.06.2017 